\title{
Eosinophil Viability-Enhancing Activity in Mite-Sensitive Bronchial Asthma
}

\author{
Mahboob Hossain, Yoshio Oкubo and Morie Sekiguchi
}

\begin{abstract}
We examined the eosinophil viability-enhancing activity (EVEA) of peripheral blood mononuclear cells (PBMNCs) obtained from 6 patients with mite-sensitive bronchial asthma (BA) and 9 normal control subjects. Mite concentrations of $1 \mu \mathrm{g} / \mathrm{ml}$ and $10 \mu \mathrm{g} / \mathrm{ml}$ significantly increased EVEA in PBMNC culture supernatants from BA patients compared with PBMNCs from normal control subjects $(76.1 \pm 11.0 \%$ at $10 \mu \mathrm{g} / \mathrm{ml}$ and $56.3 \pm 16.0 \%$ at $1 \mu \mathrm{g} / \mathrm{ml}$ vs $20.6 \pm 12.6 \%$ at $10 \mu \mathrm{g} / \mathrm{ml}$ and 7.4 $\pm 2.3 \%$ at $1 \mu \mathrm{g} / \mathrm{ml} ; \mathbf{p}<0.05)$. The level of IFN- $\gamma$ in PBMNC culture supernatants in BA patients was $2.3 \pm 0.9 \mathrm{IU} / \mathrm{ml}$ and in normal control subjects $0.7 \pm 0.3 \mathrm{IU} / \mathrm{ml}$. A combination of $\mathrm{mAbs}$ (anti-IL3, anti-IL-5 and anti-GM-CSF, with or without anti-IFN- $\gamma$ ) neutralized the EVEA $(p<0.001$, $\mathrm{p}<0.001$, respectively). Dexamethasone $\left(10^{-8} \mathrm{M}\right.$ to $\left.10^{-5} \mathrm{M}\right)$, cyclosporin $\mathrm{A}\left(10^{-7} \mathrm{M}\right.$ to $\left.10^{-5} \mathrm{M}\right)$ and FK506 $\left(10^{-8} M\right.$ to $\left.10^{-6} M\right)$ significantly inhibited EVEA in BA patients $(p<0.05$ to $p<0.001)$. The release of eosinophil cationic protein (ECP) from eosinophils in the presence of mite-stimulated PBMNC culture supernatants was higher in patients with bronchial asthma $(569 \pm 147 \mu \mathrm{g} / \mathrm{l})$ than in normal control subjects $(203 \pm 99 \mu \mathrm{g} / \mathrm{l} ; \mathbf{p}<\mathbf{0 . 0 5})$.
\end{abstract}

(Internal Medicine 33: 529-535, 1994)

Key words: eosinophil viability, cytokine, degranulation

\section{Introduction}

Bronchial asthma (BA) is a clinical syndrome characterized by the increased responsiveness of bronchoprovocative stimuli with spontaneous fluctuations in the severity of obstruction, and the infiltration of inflammatory cells (1).

The role of lymphokines in the regulation of immunoglobulin production and inflammation associated with allergy and bronchial asthma has received considerable attention. Cytokines have a broad range of cell regulatory activities both in vitro and in vivo and play an important role in many physiological responses and the pathophysiology of many diseases. Cytokines such as interleukin-5 (IL-5) (2), interleukin-3 (IL-3) (3) and granulocyte/macrophage-colony stimulating factor (GM-CSF) (4) can activate eosinophils in vitro, prolong their survival in culture and render them hypodense. Interferon- $\gamma($ IFN- $\gamma$ ) has also been reported to prolong eosinophil survival in vitro (5). IL-3 (3) and GM-CSF (4) have been found to enhance leukotriene $\mathrm{C}_{4}\left(\mathrm{LTC}_{4}\right)$ generation from eosinophils. In addition, IL-5 (2) and IL-3 (3) when cultured with eosinophils were found to enhance their helminthotoxic activity. IL-5 is also a chemoattractant for eosinophils (6). IL-5 predominate in broncho- alveolar lavage (BAL) samples from atopic patients (7).

It has been reported that eosinophils play an important role in inflammatory responses (1), suggestive of a relationship between eosinophils and monocytes or lymphocytes through various cytokines in bronchial asthma (8). In the present study eosinophil viability-enhancing activity (EVEA) was studied in mite-stimulated peripheral blood mononuclear cells (PBMNCs) obtained from mite-sensitive bronchial asthma patients and normal control subjects. Furthermore, we analyzed the EVEA and examined its response to various immunosuppressive drugs. Eosinophils have been found to release eosinophil cationic protein (ECP) in allergic diseases (9). Stimulation of eosinophils with human IgG- or human secretory $\operatorname{IgA}$ (hsIgA)-coated Sepharose 4B beads (10) induces the release of proteins, such as eosinophil-derived neurotoxin. We treated mite-stimulated culture supernatants with hsIgA-coated Sepharose $4 \mathrm{~B}$ beads to determine if they would degranulate eosinophils.

\section{Materials and Methods}

\section{Subjects}

We studied 6 bronchial asthma (BA) patients (aged 18 to 62

From the First Department of Internal Medicine, Shinshu University School of Medicine, Matsumoto

Received for publication January 10, 1994; Accepted for publication June 7, 1994

Reprint requests should be addressed to Dr. Yoshio Okubo, the First Department of Internal Medicine, Shinshu University School of Medicine, 3-1-1 Asahi, Matsumoto 390 
yr mean 35.8 \pm 7.0 ; 4 men, 2 women) (Table 1) who demonstrated prick skin test reactivity to mite and 9 nonatopic, nonsmoking normal control subjects (aged 25 to $56 \mathrm{yr}$, mean $38.8 \pm 10.8 ; 7$ men, 2 women). The patients took no drugs for bronchial asthma for one month before the experiments. Bronchial asthma was diagnosed on the basis of the criteria of the American Thoracic Society: history, physical examination, evidence of pulmonary function tests and reversible airway obstruction. Subjects were excluded from the study if they had a concurrent medical illness or were smokers.

\section{Antibodies and drugs}

Monoclonal antibodies (mAbs) against recombinant human interleukin-3 (rhIL-3), recombinant human interleukin-5 (rhIL5) and recombinant human granulocyte/macrophage-colony stimulating factor (rhGM-CSF) were donated by G. J. Gleich of Mayo Clinic (Rochester, MN, USA). Antibody against recombinant human interferon- $\gamma($ rhIFN- $\gamma)$ and dexamethasone were purchased from Genzyme Co. (Boston, MA, USA) and Sigma Chemical Co. (St. Louis, MO, USA), respectively. The drugs FK506 and cyclosporin A were donated by Fujisawa Pharmaceutical Co. Ltd. (Osaka, Japan) and Sandoz Pharmaceutical Co.(Basel, Switzerland), respectively. Dexamethasone and cyclosporin A were dissolved at a concentration of $10^{-2} \mathrm{M}$ in dimethyl sulphoxide (DMSO). FK506 was dissolved at a concentration of $10^{-2} \mathrm{M}$ in ethanol. Subsequently each solution was diluted in medium and used within $1 \mathrm{hr}$. DMSO and ethanol controls were performed in all experiments and neither vehicle alone altered eosinophil survival in the presence of PBMNC culture supernatants (data not shown).

\section{Isolation of mononuclear cells}

Peripheral blood mononuclear cells were separated from heparinized venous blood by centrifugation on a gradient of Nycoprep (Nycomed Pharma As, Oslo, Norway) according to previously described methods (11). Peripheral blood mononuclear cells were washed three times and resuspended in RPMI-1640 (GIBCO, Grand Island, NY, USA) supplemented with $50 \mu \mathrm{g} / \mathrm{ml}$ of gentamicin, $10 \%$ heat-inactivated defined calf serum (DCS) (Hyclone Laboratories Inc., Logan, UT, USA), 1

Table 1. Bronchial Asthma Patient Demographics, IgE, RAST Score and Pulmonary Function Test Results

\begin{tabular}{cccccc}
\hline No & Age (yr) & Sex (M/F) & IgE (IU/ml) & RAST & FEV1\% \\
\hline 1 & 62 & F & 41 & 3 & 71 \\
2 & 25 & M & 722 & 4 & 71 \\
3 & 24 & M & 1,550 & 4 & 76 \\
4 & 18 & F & 452 & 4 & 72 \\
5 & 50 & M & 1,669 & 4 & 64 \\
6 & 36 & M & 1,213 & 3 & 74 \\
\hline Mean \pm SEM & $35.8 \pm 7.0$ & & $941.2 \pm 262.7$ & & $71.3 \pm 1.7$ \\
\hline
\end{tabular}

M: male, F: female, RAST: radioallergosorbent test, FEV1\%: forced expiratory volume in one second over vital capacity. $\mu \mathrm{g} / \mathrm{ml}$ Polymixin B (Wako Pure Chemical Industries Ltd., Osaka, Japan), and adjusted to a concentration of $1 \times 10^{6}$ cells/ $\mathrm{ml}$. The endotoxin concentration of the mite solution $(10 \mu \mathrm{g} / \mathrm{ml})$ in culture medium was determined by the perchloric acid treatment method, and was below $20 \mathrm{pg} / \mathrm{ml}$. No spontaneous GM-CSF production by PBMNCs was observed at this concentration with polymixin B $(1 \mu \mathrm{g} / \mathrm{ml})$ (data not shown). Polymixin $B$ had no effect on EVEA at a concentration of $1 \mu \mathrm{g} / \mathrm{ml}$ (data not shown). Peripheral blood mononuclear cells $\left(0.5 \times 10^{6} / \mathrm{ml}\right)$ of BA patients (monocytes $22.0 \pm 2.0 \%$, lymphocytes $75.7 \pm 1.5 \%$, neutrophils $2.0 \pm 1.0 \%$, basophils $0.3 \pm 0.3 \%$ ) and normal control subjects (monocytes $22.2 \pm 5.2 \%$, lymphocytes $73.0 \pm 4.8 \%$, neutrophils $4.5 \pm 0.9 \%$, basophils $0.3 \pm 0.2 \%$ ) were cultured with various doses of mite $(10 \mu \mathrm{g} / \mathrm{ml}, 1 \mu \mathrm{g} / \mathrm{ml}$ and $0.1 \mu \mathrm{g} / \mathrm{ml}$ ) (Torii Pharmaceuticals Co., Tokyo, Japan) for 6 days in a humidified atmosphere of $5 \% \mathrm{CO}_{2}, 95 \%$ air at $37^{\circ} \mathrm{C}$. Culture supernatants were transferred daily to autoclaved microtubes and centrifuged at $700 \times g$ for $5 \mathrm{~min}$. Supernatants were stored at $-20^{\circ} \mathrm{C}$ until use.

\section{Effect of dexamethasone, cyclosporin A and FK506}

Peripheral blood mononuclear cells $\left(0.5 \times 10^{6} / \mathrm{ml}\right)$ from BA patients were cultured with mite $(10 \mu \mathrm{g} / \mathrm{ml})$ and various doses of dexamethasone, cyclosporin A (CsA) or FK506 in a humidified atmosphere of $5 \% \mathrm{CO}_{2}, 95 \%$ air at $37^{\circ} \mathrm{C}$. After 5 days, cell culture supernatants were transferred to microtubes and centrifuged at $700 \times g$ for $5 \mathrm{~min}$. Supernatants for eosinophil survival assay were stored at $-20^{\circ} \mathrm{C}$ until use. To examine the direct effects of dexamethasone, CsA and FK506 on eosinophil survival, mite-stimulated $(10 \mu \mathrm{g} / \mathrm{ml})$ PBMNC culture supernatants ( $25 \mu \mathrm{l} /$ well) were spiked with fresh doses of drugs.

\section{Eosinophil purification}

After informed consent, $100 \mathrm{ml}$ of heparinized venous blood was obtained from normal control subjects and mild BA patients and sedimented with 6\% dextran (Pharmacia Fine Chemicals, Uppsala, Sweden) in $0.9 \% \mathrm{NaCl}$ at a $5: 1$ ratio for $45 \mathrm{~min}$ at $37^{\circ} \mathrm{C}$. The buffy coat was collected and washed twice in Pipes (Sigma) buffer (25 mM Pipes, $50 \mathrm{mM} \mathrm{NaCl}, 5 \mathrm{mM} \mathrm{KCl}, 25 \mathrm{mM}$ $\mathrm{NaOH}, 5.4 \mathrm{mM}$ glucose) as previously described (12). The cells were suspended in $2 \mathrm{ml}$ of Percoll (Sigma) with a density of $1.070 \mathrm{~g} / \mathrm{ml}$ with $5 \%$ heat-inactivated DCS and overlayered onto a discontinuous Percoll gradient with the following densities (g/ml): 1.080, 1.085, 1.090,1.100 and 1.120. Percoll osmolarity ranged from 290 to $316 \mathrm{mOsm} / \mathrm{kg}$, with a pH of 7.3. The cells were centrifuged through the gradient at $1,500 \times g$ for $45 \mathrm{~min}$ at $4^{\circ} \mathrm{C}$ using a fixed-angle rotor. Eosinophils were collected from fractions with densities greater than $1.095 \mathrm{~g} / \mathrm{ml}$ with a peristaltic pump. Eosinophils were washed three times in Pipes buffer and stained with trypan blue and Randolph stain. The cell viability was $>98 \%$ according to trypan blue dye exclusion, and the purity of the eosinophils was determined using Randolph stain. The purities of the eosinophils for the eosinophil survival assay and degranulation assay were $>80 \%$ and $>85 \%$, respectively. Contaminating cells were shown to be neutrophils. For the eosinophil survival assay, red blood cells were lysed by hypotonic 
shock. Significant inhibitory effect of neutrophils on eosinophil survival was not observed at or below $20 \%$ of neutrophil contamination (13). The eosinophils were then washed with Hybri-Care medium (American Type Culture Collection, Rockville, MD, USA) and resuspended in Hybri-Care medium containing $10 \%$ heat-inactivated DCS, $0.1 \%$ human serum albumin (Sigma), gentamicin $(50 \mu \mathrm{g} / \mathrm{ml})$ and $2 \mathrm{mML}$-glutamine (Sigma). For the degranulation assay, eosinophils were resuspended in this medium and kept overnight at $4^{\circ} \mathrm{C}$.

\section{Eosinophil survival assay}

Freshly isolated eosinophils $\left(2.5 \times 10^{4} /\right.$ well $)$ were cultured with mite-stimulated and non-stimulated PBMNC culture supernatants $(25 \% \mathrm{v} / \mathrm{v})$ in a humidified atmosphere of $5 \% \mathrm{CO}_{2}$, $95 \%$ air at $37^{\circ} \mathrm{C}$ in 96 -well half-area flat-bottomed tissue culture plates (no. 3696, Costar, Cambridge, MA, USA). For eosinophil survival assay, the final volume was adjusted to $100 \mu \mathrm{l}$. Eosinophil viability was determined on day 4. A $10 \mu \mathrm{l}$ sample of the culture medium was carefully removed from each well and $10 \mu \mathrm{l}$ of fluorescence diacetate $(0.2 \mathrm{mg} / \mathrm{ml})$ in phosphate buffered saline at a 1:24 ratio was added to the wells. After 15min culture at $4^{\circ} \mathrm{C}$, the number of viable cells showing green fluorescence was counted under a fluorescence microscope. The total number of eosinophils was counted under a light microscope. In preliminary experiments, the number of eosinophils did not change between day 1 and day 4 and neutrophils were spontaneously lysed by day 4 (data not shown). The EVEA of PBMNC culture supernatants was calculated as follows: $\mathrm{EVEA}=$ (live eosinophils/total eosinophils $) \times 100$. Each experiment was performed in duplicate.

\section{Neutralization experiment}

Mite-stimulated culture supernatants $(25 \mu \mathrm{l})$ were reacted with monoclonal antibodies against cytokines $(1 \mu \mathrm{g} / 10 \mu \mathrm{l})$ or combinations of antibodies in 96-well half-area flat-bottomed tissue culture plates (Costar) at room temperature for $1 \mathrm{hr}$. For eosinophil survival assay, freshly isolated eosinophils $\left(2.5 \times 10^{4}\right)$ were added to each well. Preliminary studies showed that the antibodies inhibited cytokine-induced eosinophil survival in a dose-dependent manner. Antibodies $(10 \mu \mathrm{g})$ against IL-5, IL-3, GM-CSF and IFN- $\gamma$ completely neutralized rhIL-5 (300 pg), rhIL-3 (200 pg), rhGM-CSF (20 pg) and rhIFN- $\gamma$ (800 IU), respectively. Each antibody was specific for its respective cytokine (data not shown). Isotype-matched monoclonal antibody and the combinations of antibodies did not have any significant inhibitory effect in neutralization experiments (data not shown).

\section{IFN- $\gamma$ measurement}

The level of IFN- $\gamma$ in mite-stimulated culture supernatants of BA patients and normal control subjects was measured by an enzyme-linked immunosorbent assay (ELISA) kit (Medgenix Diagnostics, Fleurus, Belgium).

Eosinophil degranulation of PBMNC culture supernatants

Sepharose $4 \mathrm{~B}$ beads were coated with hsIgA (Accurate
Chemical Scientific Corporation, Westbury, NY, USA) as described previously (10). Eosinophils were washed with HybriCare medium (American Type Culture Collection, Rockville, MD, USA) containing $0.1 \%$ human serum albumin, gentamicin $(50 \mu \mathrm{g} / \mathrm{ml})$ and L-glutamine $(2 \mathrm{mM})$ and resuspended at a concentration of $2.5 \times 10^{5} / 100 \mu$ l. Eosinophils $\left(2.5 \times 10^{5}\right)$ were incubated with $50 \mu \mathrm{l}$ of mite-stimulated culture supernatants from BA patients and normal control subjects for 1 hour and then with $50 \mu \mathrm{l}$ of hsIgA-coated Sepharose 4B beads (cells: beads $=20: 1$ ) for 4 hours in 96-well round-bottomed tissue culture plates (no. 63320, Intermed Nunc, Roskilde, Denmark) in a humidified atmosphere of $5 \% \mathrm{CO}_{2}, 95 \%$ air at $37^{\circ} \mathrm{C}$. Plates were centrifuged at $1,000 \times g$ for $10 \mathrm{~min}$ at $4^{\circ} \mathrm{C}$. Supernatants were then collected and stored at $-20^{\circ} \mathrm{C}$ until assayed. ECP contents were then measured with an ECP-kit (Pharmacia Fine Chemicals, Uppsala, Sweden).

\section{Statistical analysis}

All values are expressed as means \pm standard error of the mean (SEM). Differences among groups were evaluated by one factorial ANOVA.

\section{Results}

\section{Dose-response and time course}

The EVEA in response to mite concentrations of $1 \mu \mathrm{g} / \mathrm{ml}$ and $10 \mu \mathrm{g} / \mathrm{ml}$ was significantly higher in BA patients than in normal control subjects $(\mathrm{p}<0.05, \mathrm{p}<0.05$, respectively; Fig. 1). The EVEA in BA patients was significantly higher at mite concentrations of $1 \mu \mathrm{g} / \mathrm{ml}$ and $10 \mu \mathrm{g} / \mathrm{ml}$ than at $0 \mu \mathrm{g} / \mathrm{ml} \quad(\mathrm{p}<0.05$, $\mathrm{p}<0.05$, respectively). However, the EVEA at $10 \mu \mathrm{g} / \mathrm{ml}$ was not significantly higher than at $0 \mu \mathrm{g} / \mathrm{ml}$ in normal control subjects. Even at a mite concentration of $0 \mu \mathrm{g} / \mathrm{ml}$ the EVEA was somewhat higher in BA patients than in normal control subjects $(\mathrm{p}<0.1)$. EVEA was dependent on the duration of culture and reached a plateau on day 5 or day 6 (data not shown). Therefore, subsequent experiments were conducted with $10 \mu \mathrm{g} / \mathrm{ml}$ of mite and a 5-day culture period.

\section{Neutralization experiment}

Figure 2 shows that anti-IFN- $\gamma$ mAb alone significantly neutralized the EVEA of BA patients and that the EVEA remained practically unchanged in the absence of antibodies $(\mathrm{p}<0.05)$. The combination of anti-IL-3 and anti-GM-CSF $(\mathrm{p}<0.05)$ as well as anti-IL-5 and anti-GM-CSF mAbs $(\mathrm{p}<0.01)$ also significantly neutralized the EVEA as did a combination of anti-IL-3, anti-IL-5, anti-GM-CSF ( $\mathrm{p}<0.001)$. The combination of anti-IL-3, anti-IL-5, anti-GM-CSF and anti-IFN- $\gamma$ almost completely neutralized EVEA $(\mathrm{p}<0.001)$, indicating that IL-3, IL-5, GM-CSF and IFN- $\gamma$ may be involved in EVEA.

\section{Production of IFN- $\gamma$}

IFN- $\gamma$ production of mite-stimulated PBMNCs was significantly higher in BA patients $(2.3 \pm 0.9 \mathrm{IU} / \mathrm{ml})$ than in normal control subjects $(0.7 \pm 0.3 \mathrm{IU} / \mathrm{ml}, \mathrm{p}<0.05)$. 


\section{Hossain et al}

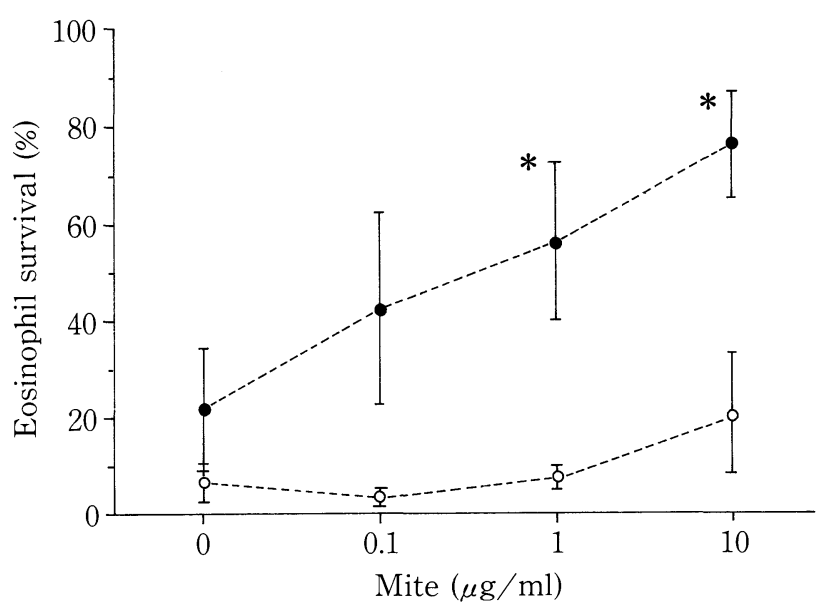

Fig. 1. Peripheral blood mononuclear cells $\left(0.5 \times 10^{6} / \mathrm{ml}\right)$ were cultured with various doses of mite for 5 days. Eosinophils $\left(2.5 \times 10^{4} /\right.$ well $)$ were cultured with $(25 \% \mathrm{v} / \mathrm{v})$ peripheral blood mononuclear cells (PBMNCs) culture supernatants obtained from bronchial asthma patients ( $\mathrm{n}=6$, closed circles) and normal control subjects ( $n=9$, open circles) in the presence or absence of mite. Values represent the mean percentages of viable cells $(\%) \pm$ SEM. ${ }^{*} \mathrm{p}<0.05$; significant difference between normal group and asthma group.

Antibody

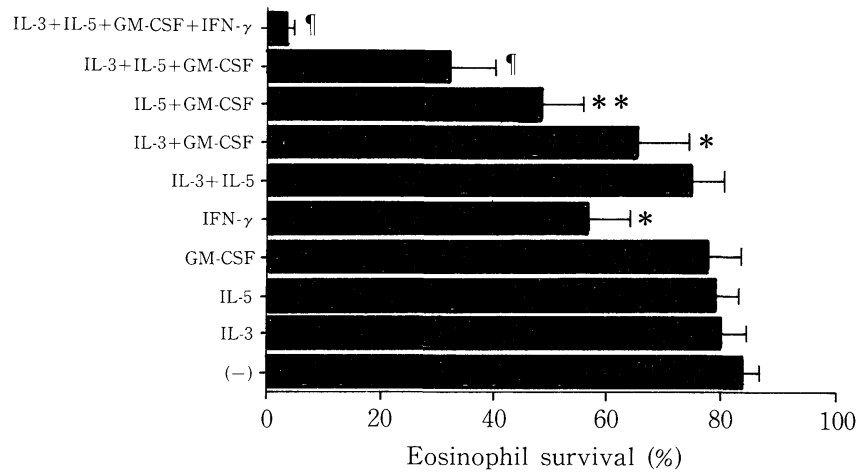

Fig. 2. Neutralization of mite-stimulated peripheral blood mononuclear cells (PBMNCs) $\left(0.5 \times 10^{6} / \mathrm{ml}\right)$ culture supernatants from bronchial asthma patients $(n=6)$ by monoclonal antibodies $(1 \mu \mathrm{g} / 10 \mu \mathrm{l})$ against recombinant human interleukin 3 (rhIL-3), recombinant human interleukin-5 (rhIL-5), recombinant human granulocyte/macrophage-colony stimulating factor (rhGM$\mathrm{CSF})$ and recombinant human interferon- $\gamma(\mathrm{rhIFN}-\gamma)$. Values are means \pm SEM. ${ }^{*} \mathrm{p}<0.05 ; * * \mathrm{p}<0.01 ; \uparrow \mathrm{p}<0.001 ;$ significant difference between with and without $\mathrm{mAb}(\mathrm{s})$.

\section{Effects of drugs on EVEA}

Figure 3 shows that the direct effect of dexamethasone was not significant on the EVEA of mite-stimulated culture supernatants between $0 \mathrm{M}$ and $10^{-8} \mathrm{M}, 10^{-7} \mathrm{M}, 10^{-6} \mathrm{M}, 10^{-5} \mathrm{M}$, respectively. However, the EVEA of PBMNCs from BA patients in the presence of dexamethasone at $10^{-8} \mathrm{M}, 10^{-7} \mathrm{M}$, $10^{-6} \mathrm{M}$ and $10^{-5} \mathrm{M}$ was significantly reduced compared with EVEA at $0 \mathrm{M}(\mathrm{p}<0.05, \mathrm{p}<0.001, \mathrm{p}<0.001, \mathrm{p}<0.001$, respectively). Significant inhibition by dexamethasone on the EVEA

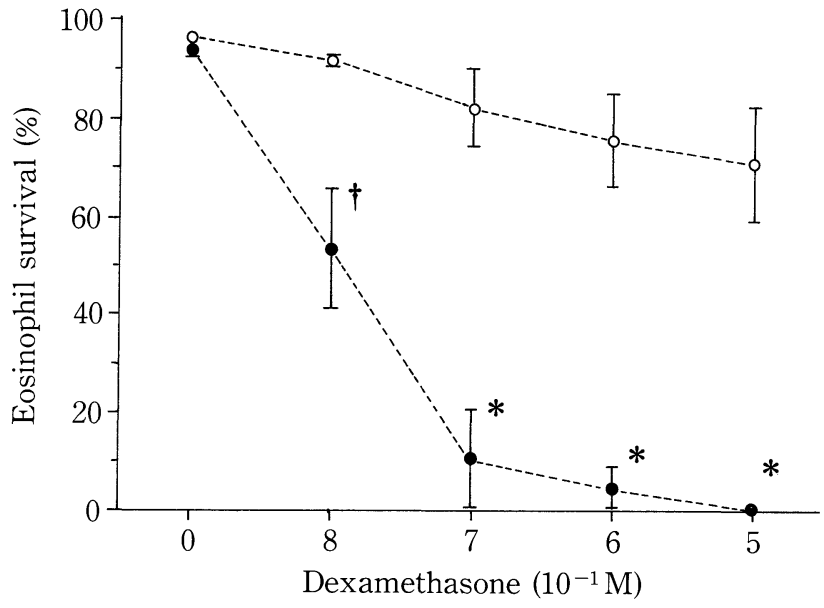

Fig. 3. The effect of dexamethasone on eosinophil viability enhancing activity (EVEA). The mite-stimulated EVEA of bronchial asthma patients ( $\mathrm{n}=6$ ) was significantly inhibited at concentrations from $10^{-8} \mathrm{M}$ to $10^{-5} \mathrm{M}$ compared with EVEA at $0 \mathrm{M}$ (closed circles). In contrast, the direct inhibitory effect of dexamethasone on EVEA at $10^{-8} \mathrm{M}, 10^{-7} \mathrm{M}, 10^{-6} \mathrm{M}$ and $10^{-5} \mathrm{M}$ was not significant compared with the effect at $0 \mathrm{M}$ (open circles). ${ }^{*} \mathrm{p}<0.001$; $\dagger \mathrm{p}<0.05$; significant difference between with and without drug.

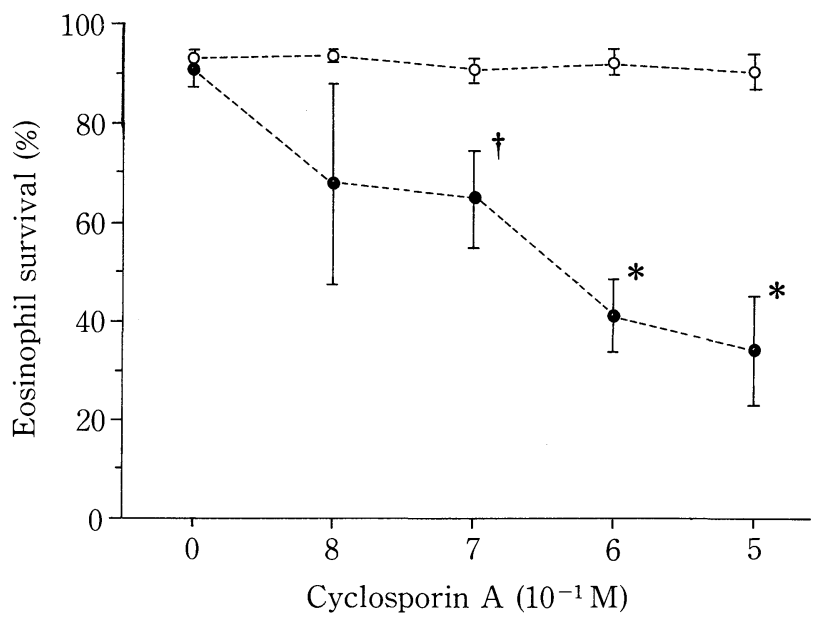

Fig. 4. The effect of cyclosporin A on eosinophil viability enhancing activity (EVEA). The mite-stimulated EVEA of bronchial asthma patients $(\mathrm{n}=6)$ was significantly inhibited at concentrations from $10^{-7} \mathrm{M}$ to $10^{-5} \mathrm{M}$ compared with the EVEA at $0 \mathrm{M}$ (closed circles). In contrast, the direct effect of cyclosporin A on EVEA at $10^{-7} \mathrm{M}, 10^{-6} \mathrm{M}$ and $10^{-5} \mathrm{M}$ was not significant compared with the effect at $0 \mathrm{M}$ (open circles). ${ }^{*} \mathrm{p}<0.001 ; \dagger \mathrm{p}<0.05$; significant difference between with and without drug.

of mite-stimulated culture supernatants was observed at $10^{-8}$ $\mathrm{M}, 10^{-7} \mathrm{M}, 10^{-6} \mathrm{M}$ and $10^{-5} \mathrm{M}$ of dexamethasone, corresponding to the same concentrations in the direct effect of dexamethasone $(\mathrm{p}<0.02, \mathrm{p}<0.001, \mathrm{p}<0.001, \mathrm{p}<0.001)$. Cyclosporin $\mathrm{A}\left(10^{-7} \mathrm{M}\right.$ to $\left.10^{-5} \mathrm{M}\right)$ and FK506 $\left(10^{-8} \mathrm{M}\right.$ to $\left.10^{-6} \mathrm{M}\right)$ had effects similar to those of dexamethasone (Figs. 4 and 5). 


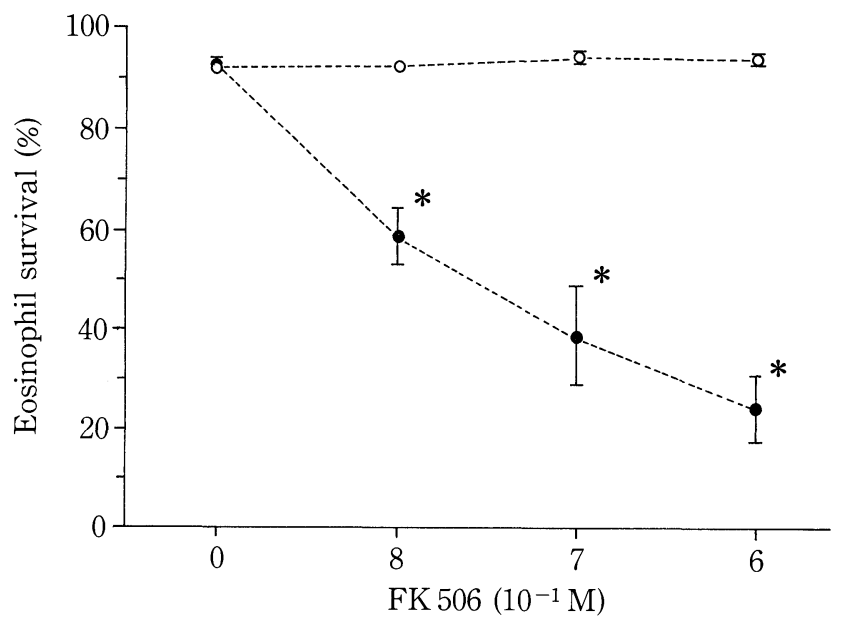

Fig. 5. The effect of FK506 on EVEA. The mite-stimulated EVEA of bronchial asthma patients $(n=6)$ was significantly inhibited at concentrations from $10^{-8} \mathrm{M}$ to $10^{-6} \mathrm{M}$ compared with EVEA at $0 \mathrm{M}$ (closed circles). In contrast, the direct effect of FK506 on EVEA was not significant at $10^{-8} \mathrm{M}, 10^{-7} \mathrm{M}$ and $10^{-6} \mathrm{M}$ compared with the effect at $0 \mathrm{M}$ (open circles). ${ }^{*} \mathrm{p}<0.001$; significant difference between with and without drug.

\section{The effect of PBMNC culture supernatants on ECP release}

Eosinophil cationic protein release in the presence of mitestimulated PBMNC culture supernatants was significantly higher in BA patients $(569 \pm 147 \mu \mathrm{g} / \mathrm{l})$ than in normal control subjects $(203 \pm 99 \mu \mathrm{g} / \mathrm{l}, \mathrm{p}<0.05)$.

\section{Discussion}

Since the mite was identified as the most important source of house dust allergen 25 years ago, there has been steady progress in understanding the way in which the mite contributes to asthma (14). Bronchial asthma is characterized by marked inflammation in the airways associated with infiltrating inflammatory cells, particularly eosinophils, and destruction of airway epithelium. The development and function of eosinophils are regulated by a number of cytokines, such as IL-3, IL-5 and GM-CSF. Eosinophils can survive for a long time in the presence of IL-3, IL-5, GM-CSF and IFN- $\gamma$ (5). Eosinophil survival assay is a more sensitive method of measuring eosinophil-active cytokines than the ELISA assay (15). Using an eosinophil survival assay we reported previously that it is possible to detect IL-3, IL-5, GM-CSF and IFN- $\gamma$ from $1 \mathrm{pg} / \mathrm{ml}$ to $100 \mathrm{pg} / \mathrm{ml}$ (13), $1 \mathrm{pg} / \mathrm{ml}$ to $100 \mathrm{pg} / \mathrm{ml}$ (13), $0.1 \mathrm{pg} / \mathrm{ml}$ to $10 \mathrm{pg} /$ $\mathrm{ml}$ (13) and $1 \mathrm{IU} / \mathrm{ml}$ to $10 \mathrm{IU} / \mathrm{ml}$ (our unpublished observation), respectively. In the present study, anti-IFN- $\gamma \mathrm{mAb}$ alone significantly inhibited EVEA and we also measured IFN- $\gamma$ by ELISA.

A combination of IL-3, IL-5 and GM-CSF mAbs showed significant inhibition of EVEA, although we could not measure IL-3, IL-5 or GM-CSF using ELISA because of low sensitivity. However, neutralization experiments using an eosinophil survival assay indicated that IL-3, IL-5, GM-CSF and IFN- $\gamma$ are involved in EVEA and we could detect the amount of IFN- $\gamma$ using ELISA. Furthermore, eosinophil survival assay showed that EVEA may be produced spontaneously in BA patients, suggesting the existence of activated cytokine-producing cells.

Mosmann and Coffman (16) reported that mouse TH1 clones produced IL-2, IFN- $\gamma$, IL-3 and GM-CSF, while TH2 clones produced IL-4, IL-5, IL-6, IL-3 and GM-CSF. Similar findings in the BAL samples from patients with atopic asthma have been reported in humans (17). Ellaurie and coworkers (18) reported that IFN- $\gamma$ production was much higher in mite-sensitive BA patients than in normal control subjects. It was recently reported that antigen-specific clones established from atopic donors produced IL-4 and IL-5 (19). Parronchi and coworkers (20) reported that Dermatophagoides pteronyssinus group (Der P1)-specific CD4 ${ }^{+}$T-cell clones produced IL-4 and IL-5 and variable amounts of IL-2, but produced only small amounts of IFN- $\gamma$. The PBMNCs of the BA patients in the present study appeared to contain two types of clones, similar to mouse TH1 and $\mathrm{TH} 2$ clones, because mite-stimulated PBMNCs supernatants contained IFN- $\gamma$, IL-3, IL-5 and GM-CSF. However, high levels of IL-5 in BAL samples (16), CD-25-positive lymphocytes containing IL-5 mRNA (21) and IL-5 mRNA-positive cells in bronchial biopsies from patients with asthma (17) have been reported, suggesting that local mononuclear cells produce a greater amount of IL-5 in the lung. This discrepancy may be due to different distributions and properties of mononuclear cells. Furthermore, IFN- $\gamma$ production of PBMNCs in this study may play an important role in the expression of endothelial adhesion molecules (22) and migration of eosinophils from peripheral blood to the lung. In this study, mite-stimulated monocytes may be involved in IFN- $\gamma$ production through tumor necrosis factor-alpha and interleukin 1-alpha (8).

In the present study, dexamethasone significantly inhibited EVEA. Larsson (23) also observed that dexamethasone at a concentration of $10^{-6} \mathrm{M}$, achieved clinically with commonly used steroid dosage regimens (24), markedly reduced T-cell growth factor (TCGF) production. Dexamethasone has been found to specifically inhibit induction of both TCGF and IFN$\gamma$ mRNA in normal lymphocytes (25). Glucocorticoid induces apoptosis in lymphocytes (26). It is thought that inhibition of EVEA may be due to a steroid-dependent activation of an endonuclease that degrades nuclear DNA (27). Cyclosporin A and FK506 also significantly inhibited EVEA. Reem and Cook (28) reported that CsA suppressed the synthesis of IFN- $\gamma$ by human thymocytes and T-lymphocytes in vitro. Herold and colleagues (29) reported that CsA inhibited production of IL-2, IL-3, and IFN- $\gamma$. FK506 and CsA have been reported to inhibit signal transduction pathways that lead to T-lymphocyte activation $(30,31)$. Moreover, Colombani and colleagues (32) observed that CsA binds with calmodulin (a protein essential for normal cell function) and thus interrupts T-lymphocyte activation. The presence of cyclophilin (CsA receptor) and FKBP (FK506 receptor) in many organisms suggests that these enzymes may have some general cellular functions. Complexes of cyclophilin-CsA and FKBP-FK506 were reported to bind competitively to $\mathrm{Ca}^{2+}$ and inhibit calmodulin-dependent phos- 
phatase, and thus inhibit normal cell functions (33). The present data suggests that dexamethasone, CsA and FK506 inhibited production of IFN- $\gamma$ in addition to IL-3, IL-5 and GM-CSF. It has been reported that CsA improved lung function of corticosteroid-dependent BA patients (34). Also, FK506 may be useful in the treatment of bronchial asthma.

We found that mite-stimulated PBMNC culture supernatants significantly increased ECP release from eosinophils, suggesting that production of cytokines by patients' $\mathrm{PBMNCs}$ leads to eosinophil degranulation (35), hypodense eosinophils (36) and considerable tissue damage when released extracellularly (37).

Our results suggest that mite-stimulated PBMNCs play an important role in the production of IL-3, IL-5, GM-CSF and IFN- $\gamma$ and that their culture supernatants can degranulate eosinophils. Furthermore, immunosuppressive drugs may be clinically useful for the treatment of BA involving cytokine production.

Acknowledgements: Monoclonal antibodies against recombinant human IL-3 (rhIL-3), recombinant human IL-5 (rhIL-5) and recombinant human GMCSF (rhGM-CSF) were donated by Dr. G. J. Gleich of Mayo Clinic (Rochester, MN, USA). Cyclosporin A and FK506 were donated by Fujisawa Pharmaceutical Co. Ltd. (Osaka, Japan) and Sandoz Pharmaceutical Co. (Basel, Switzerland), respectively. Other expenses was supported by Ministry of Education.

\section{References}

1) American Thoracic Society. Standards for the diagnosis and care of patients with chronic obstructive pulmonary disease (COPD) and asthma. Am Rev Respir Dis 136: 225, 1987.

2) Rothenberg ME, Petersen J, Stevens RL, et al. IL-5 dependent conversion of normodense human eosinophils to the hypodense phenotype uses 3T3 fibroblasts for enhanced viability, accelerated hypodensity, and sustained antibody-dependent cytotoxicity. J Immunol 143: 2311, 1989.

3) Rothenberg ME, Owen WF Jr, Silberstein DS, et al. Human eosinophils have prolonged survival, enhanced functional properties, and become hypodense when exposed to human interleukin 3. J Clin Invest 81: 1986, 1988.

4) Owen WF Jr, Rothenberg ME, Silberstein DS, et al. Regulation of human eosinophil viability, density, and function by granulocyte/macrophage colony-stimulating factor in the presence of 3T3 fibroblasts. J Exp Med 166: 129, 1987.

5) Valerius T, Repp R, Kalden JR, Platzer E. Effects of IFN on human eosinophils in comparison with other cytokines: Anovel class of eosinophil activators with delayed onset of action. J Immunol 145: 2950, 1990.

6) Yamaguchi $Y$, Hayashi $Y$, Sugama $Y$, et al. Highly purified murine interleukin 5 (IL-5) stimulates eosinophil function and prolongs in vitro survival: IL-5 as an eosinophil chemotactic factor. J Exp Med 167: 1737, 1988.

7) Sedwick JB, Calhoun WJ, Gleich GJ, et al. Immediate and late airway response of allergic rhinitis patients to segmental antigen challenge: Characterization of eosinophil and mast cell mediators. Am Rev Respir Dis 144: 1274, 1991.

8) Kay AB. Asthma and inflammation. J Allergy Clin Immunol 87: 893, 1991.

9) Dahl R, Venge P, Olsson I. Variations of blood eosinophils and eosinophil cationic protein in serum in patients with bronchial asthma: Studies during inhalation challenge test. Allergy 33: 211, 1978.

10) Abu-Ghazaleh RI, Fujisawa T, Mestecky J, Kyle RA, Gleich GJ. IgAinduced eosinophil degranulation. J Immunol 142: 2393, 1989.

11) Rickwood D, Ford TC, Graham J Nycodenz. A new nonionic density gradient medium. Anal Biochem 123: 23, 1982.
12) Kita H, Ohnishi T, Okubo Y, WeilerD, Abrams JS, Gleich GJ.Granulocyte/ Macrophage colony-stimulating factor and interleukin 3 release from human peripheral blood eosinophils and neutrophils. J Exp Med 174: 745, 1991.

13) Okubo Y, Kita H, Weiler D, Abrams JS, Gleich GJ. Sensitivity of the eosinophil survival assay for IL-3, GM-CSF and IL-5. FASEB J 5: 641, 1991 (Abstract).

14) Platts-Mills TAE, Chapman MD. Dust mites: immunology, allergic disease, and environmental control. J Allergy Clin Immunol 80: 755, 1987.

15) Ohnishi T, Kita H, Weiler D, et al. IL-5 is the predominant eosinophilactive cytokine in the antigen-induced pulmonary late-phase reaction. Am Rev Respir Dis 147: 901, 1993.

16) Mosmann TR, Coffman RL. TH1 and TH2 cells: Different patterns of lymphokine secretion lead to different functional properties. Am Rev Immunol 7: 145, 1989.

17) Robinson DS, Hamid Q, Ying $S$, et al. Predominant $T_{H 2}$-like bronchoalveolar T-lymphocyte population in atopic asthma. J Engl J Med 326: 298, 1992.

18) Ellaurie M, Yost SL, Rosentreich DL. A simplified human whole blood assay for measurement of dust mite-specific gamma interferon production in vitro. Ann Allergy 66: 143, 1991.

19) Parronchi P, Macchia D, Piccini MP, et al. Allergen- and bacterial antigen-specific T-cell clones established from atopic donors show a different profile of cytokine production. Proc Natl Acad Sci USA 88: 4538, 1991.

20) Parronchi P, Manetti R, Simonelli C, et al. Cytokine production by allergen (Der P1)-specific CD4 ${ }^{+} \mathrm{T}$-cell clones derived from a patient with severe atopic disease. Int J Clin Lab Res 21: 186, 1991.

21) Hamid Q, Azzawi M, Ying S, et al. Expression of mRNA for interleukin5 in mucosal bronchial biopsies from asthma. J Clin Invest 87: 1541, 1991.

22) Pober JS, Gimbrone MA Jr., Lapierre LA, et al. Overlapping patterns of activation of human endothelial cells by interleukin 1, tumor necrosis factor, and immune interferon. J Immunol 137: 1893, 1986.

23) Larsson EL. Cyclosporin $A$ and dexamethasone suppress $T$ cell responses by selectively acting at distinct sites of the triggering process. J Immunol 124: 2828, 1980.

24) Georgitis JW, Kathleen A, Flesher RN, Szefler SJ. Bioavailability assessment of a liquid prednisone preparation. J Allergy Clin Immunol 70: 243, 1982.

25) Arya SK, Wong-staal F, Gallo RC. Dexamethasone-mediated inhibition of human $\mathrm{T}$ cell growth factor and $\gamma$-interferon messenger RNA. J Immunol 133: 273, 1984.

26) Wyllie AH. Glucocorticoid-induced thymocyte apoptosis is associated with endogenous endonuclease activation. Nature 284: 555, 1980.

27) Cohen JJ, Duke RC. Glucocorticoid activation of a calcium-dependent endonuclease in thymocyte nuclei leads to cell death. J Immunol 132: 38, 1984.

28) Reem GH, Cook LA. Gamma interferon synthesis by human thymocytes and T-lymphocytes inhibited by cyclosporin A. Science 221: 63, 1983.

29) Herold KC, Lancki DW, Moldwin RL, Fitch FW. Immunosuppressive effects of cyclosporin A on cloned T-cells. J Immunol 136: 1315, 1986.

30) Schreiber SL. Chemistry and biology of the immunophilins and their immunosuppressive ligands. Science 251: 283, 1991.

31) Heitman J, Movva NR, Hall MN. Proline isomerases at the crossroad of protein folding signal transduction and immunosuppression. New Biol 4: $448,1992$.

32) Colombani PM, Robb A, Hess AD. Cyclosporin A binding to calmodulin: A possible site of action of T-lymphocytes. Science 228: 337, 1985.

33) Liu J, Farmer JD Jr, Lane WS, Friedman J, Weissman I, Schreiber SL. Calcineurin is a common target of cyclophilin-cyclosporin A and FKBPFK506 complexes. Cell 66: 807, 1991.

34) Alexander GA, Barnes NC, Kay AB. Trial of cyclosporin in corticosteroiddependent chronic severe asthma. Lancet 339: 324, 1992.

35) Fujisawa T, Abu-Ghazaleh R, Kita H, Sanderson CJ, Gleich GJ. Regula- 


\section{Eosinophil Viability in Asthma}

tory effect of cytokines on eosinophil degranulation. J Immunol 144: 642, 1990.

36) Fukuda T, Dunnette SL, Reed CE, Ackerman SJ, Peters MS, Gleich GJ. Increased numbers of hypodense eosinophils in the blood of patients with bronchial asthma. Am Rev Respir Dis 132: 981, 1985.

37) Gleich GJ, Frigas E, Loegering DA, Wasson DL, Steinmuller D. Cytotoxic properties of the eosinophil major basic protein. J Immunol 123: 2925, 1979. 